with $£ 329$ million for the bridge and $£ 160$ million for the rail tunnel.

The proposals for a bridge and for a road tunnel both rely largely on tax reliefs to improve the financial prospects of their respective projects, but the risks do not appear to be excessively high, and while the means of Government assistance here proposed may be open to objection. the decision as to whether the projert should be supported or not is one for Government level. The decision, moreover, is urgent and ought not to be postponed. If the determining considerations are those that fall outside the scope of the working party itself, and even if the proposals represent little that could not have been advanced half a century or more earlier, to delay is only to increase the ultimate cost of a favourable decision- $\mathbf{a}$ cost that has multiplied many times since the proposa] was first advanced in the last century (see, for example, Nature, $1,160,303,631 ; 1869)$.

\title{
EMPLOYMENT OF WOMEN IN INDUSTRY
}

\section{A} RECENT investigation of the industrial employment of women throughout their middle working lives*, to which the Director of the Nuffield Foundation contributes a foreword, is essentially in continuation of the investigations which the Foundation has for some time been promoting on the employment prospects of older men. Insisting that the basic unit of society is the indissoluble complex of relationships that controls both men and women, $\mathrm{Mr}$. Le Gros Clark takes account of this subtle but changing element in dealing with the influx of women into employment. Considering first the life rhythms of modern women, he concludes that there will be far fewer single women in middle life and a diminishing number of widows, though this large impact of widowhood will not be felt until most married women are passing beyond their employable age. Of necessity, if employers still need female labour, they will have to depend on married women, and mostly on those of mature years. Moreover, Mr. Le Gros Clark insists also on the importance of the contribution which married women and mothers make outside the labour market; he regards as misleading the classification of many women by economists as merely 'dependants'. Women as a whole are not free to go out to work until they feel that they have among them accounted for their multifarious domestic and family commitments.

His analysis of available and relevant figures of part. time employment indicates that age makes remarkably little difference in the opportunities most women have of limiting the hours they work, and that the older women still have their domestic commitments as well as some impairment of health in mind when they stipulate for a part-time job. Most of them would also seem to take it for granted that at their age they may have to gravitate to a catering, domestic or cleaning job. Now that working hours per week are contracting in most industries, the stipulations made by many married women seem likely to appear more realistic. It is not easy to say at what

* Woman, Work and Age: To Study the Emploument of Working Women Throughout Their Middle Lives. By F. Le Gros Clark. Pp. 111 (London: The Nuffield Foundation, 1963.) 78. 6d. net. ages and for what reasons women finally move out of the labour market, but, in the present state of medical knowledge, women seem more susceptible than men to the kinds of ailment which one might expect to hasten their withdrawal from work outside their homes.

Their rates of withdrawal from the manufacturing industries are most noticeable, and while the possibility of moving the older married women to lighter or modified work requires examination, it can at least be said that, although most middle-aged women are not on such exacting work, the differential withdrawal rate among those who are could easily affect the average rate at which women leave employment. At present they do so in substantial numbers in their early fifties, and probably nearly one in three has departed by the time they approach sixty. Some leave by choice and some subject to retirement regulations, but a proportion which is not negligible complain of industrial strain or incipient ill-health, so that women still at work in their late sixties represent only about a quarter of those who are at work ten years younger, and most are working on their own or managing the work of others, or in some 'domestic' form of employment.

Mr. Le Gros Clark suggests some of the female-male adjustments that are likely to be needed particularlv if middle-aged married women are required in employment. In large measure he predicts they will be able to make their own terms, particularly about their hours of work. This is likely to be felt particularly in health, welfare and educational services, but he suggests too that the amenities, the codes of behaviour and the conventions habitual through industry are likely to be affected ultimately. He points to the desirability, in the general education of girls, of making an effort to break down the barrier between the sciences and the arts and of stressing the æsthetic qualities of the former subjects. This is largely a matter of finding imaginative teachers, but it has a great bearing on equipping girls for life, especially as, ultimately, married women may have to show themselves more prepared to take on posts of skill and responsibility.

\section{SCIENTIFIC RESEARCH IN BELGIUM}

T HE annual report for 1962 of the National Council for Scientific Policy, Brussels*, is of special interest in view of the present discussions on scientific policy in Western Europe generally. Moreover, it exemplifies the type of report which the Office of the Ministry for Science might be expected to provide regularly for the United Kingdom and which, on a lesser scale, the annual report of the Advisory Council on Scientific Policy has sometimes supplied in part. Following an introduction, the report is in two parts: the first outlines the functions of the Council, including the general structure of scientific

* Conseil National de Ia Politique Scientiflque. Rapport Annuel, 1963. Pp. 171. (Bruxelles: Conseil National de la Politique Scientifique 1963.) work in Belgium; the second records the activities of the Council during December 1, 1961--December 1, 1962, including those of its committees and institutions and Government measures affecting the work of the Council. Among appendixes which list the membership of various committees, etc., is a note on the meeting of the Ministerial Committee for Scientific Policy and the Bureau of the Council last July at which the Budget for 1963 was fixed at 4,904 million franes, a 20 per cent inerease on the previous year, and including an 18 per cent inerease for the universities.

The first part of the report is of the most general interest. The budget for 1962 was for 4,080 million francs, an increase of 14.4 per cent over 1961. Of this, 2,316 
million francs were for education, 1,156 million francs for oconomic interests, 179 million franes for agriculture, 153 million franes for defence (a decrease of 9 per cent) and 77 million francs for public health. By institutions the distribution of the budget is as follows (figures in brackets give the percentage increase on 1961): universities and other higher educational institutions, 2,434 million francs $(11 \cdot 2)$; State sciontific establishments, 748 million francs $(11 \cdot 7)$; public service institutions supported by the State, 627 million francs (27); industrial enterprises and co-operative centres, 170 million francs $(16.4)$; and international organizations, 101 million francs $(-6 \cdot 5)$. By sciences, etc., the distribution is as follows: fundamental research, 533 million francs (16), of which 221 million francs was for the exact sciences, 114 million france for biology and other natural sciences, and 80 million francs for the medical sciences, 601 million francs for applied research (18), of which 276 million francs was for agriculture and veterinary medicine and 325 million francs for industrial research; 826 million francs for nuclear science $(19 \cdot 7)$ and 120 million francs for economic and social science $(33 \cdot 3)$.

The second chapter of this first part of the report analyses further the research effort as supported by the Foundation for Scientific Research, and in special fields such as nuclear energy and space research, for which $14 \cdot 8$ million francs was allocated among four groups. Fifteen groups working on molecular biology received 26 million francs; six on medical enzymology, 3 million francs; and seven on human geneties, 4.5 million francs. Information regarding the universities, similar to, but less detailed than, that supplied in the annual returns from the University Grants Committee, is contained in the following chapter, which also includes figures for tho support and staff of national scientific institutions. Student numbers at the four universities of Ghent, Liège, Brussels and Louvain have risen by $23 \cdot 7$ per cent since 1958 to 28,346 in 1962, and other institutions of higher learning bring this total to 32,726 . University grants have increased in the same period from 646 to $1,336 \cdot 5$ million francs.

\section{STRYCHNINE-RESISTANT CENTRAL INHIBITION}

\section{Strychnine-resistant Inhibition in the Brain}

T the spinal cord it has boen shown that strychnine 1 very effectively depresses the activity of the postsynaptic inhibitory synapses which are formed by a variety of pathways converging on motoneurones ${ }^{1-4}$. Strychnine depresses the inhibitory action of the olivo-cochlear bundle on sensory fibre terminals and on the hair cells of the organ of Corti ${ }^{5}$. Since this alkaloid has this specific depressant action on so many types of inhibitory synapses it has been suggested that it acts competitively against the same inhibitory transmitter substance ${ }^{6}$. Large and prolonged inhibitory postsynaptic potentials (IPSPs) have been recorded from a variety of neurones in the higher centres of the brain : pyramidal cells of the motor corte $x^{7-10}$, of the sensory cortex $x^{11-13}$ and of the hippocampus ${ }^{14,15}$; and also mitral cells of the olfactory bulb ${ }^{16}$, cerebellar Purkinjo cells ${ }^{17,18}$ and thalamic neurones ${ }^{18-21}$. If there is the same inhibitory transmitter at all these synapses, it would be expected that strychnine would similarly be a very effective dopressant.

However, Green, Mancia and Baumgarten ${ }^{22}$ and Baumgarten, Green and Mancia ${ }^{23}$ found that strychnine failed. to block the inhibition of mitral cells and cells of the plexiform layer of the olfactory bulb in response to stimulation of the lateral olfactory tract and of the anterior commissure. In the investigation reported here it is shown that strychnine is without any detectable effect on three examples of postsynaptic inhibition in the brain even when given in doses that virtually eliminate postsynaptic inhibition in the spinal cord.

Adult cats were anæsthetized by pentobarbital sodium and intracellular rocordings made by glass microelectrodes filled with solutions of $3 \mathrm{M}$ potassium chloride (5-40 M $\Omega$ ) or $2 \mathrm{M}$ potassium citrate (7-30 $\mathrm{M} \Omega$ ). Microelectrodos filled with $4 \mathrm{M}$ sodium chloride (1-4 M $\Omega$ ) were usually used for extracellular recording.

In Fig. $1 A$ are the intracellular and just extracellular records from a hippocampal pyramidal cell in response to stimulation of the fimbria hippocampi. Subtraction of these two records revoals that the pyramidal cell had responded by a typical large and prolonged inhibitory postsynaptic potential. In Fig. $1 B$ it is seen that $10 \mathrm{~min}$ after the intravenous injection of $0.3 \mathrm{mg}$ strychnine hydrochloride per $\mathrm{kg}$ body-weight a similar inhibitory potential was evoked in another pyramidøl cell close to the first. Postsynaptic inhibitory potentials of comparable amplitude and duration were observed in 174 out of 178 impaled hippocampal cells in strychnine-free preparations and
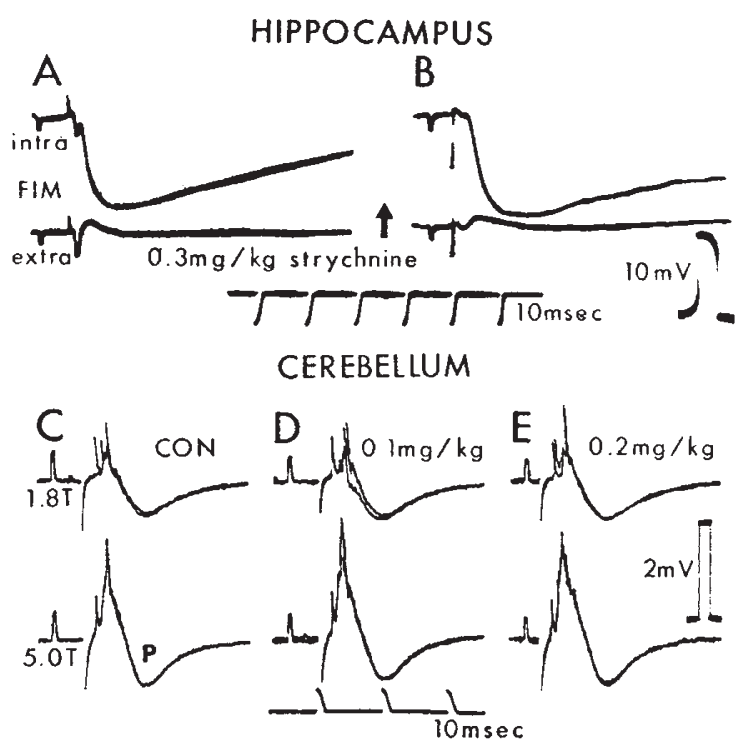

THALAMUS
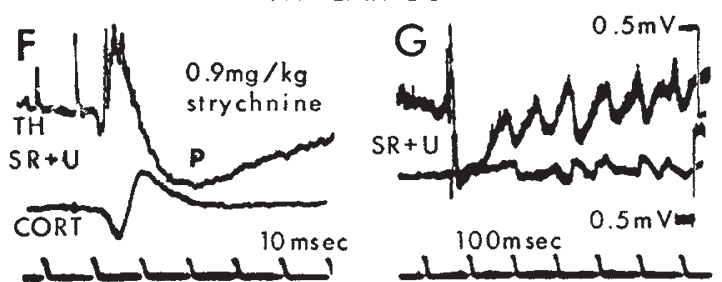
Fig. 1. A, inhibitory postsynaptic potential from hippocampal pyramidal potential after intravenous injection of $0 \cdot 3 \mathrm{mg}$ strychnine hydrochloride per kg. intra, intracellular; extra, extracellular recording. In $A$ and $B$ per kg. intra, intracellular; $C x t r a$, extraceliular recording. In $A$ and $B$
positivity is upwards; in $C-G$ positivity is downwards. $C$, responses
evoked by stimulation of parallel fibres at 1.8 and five times threshold (upper and lower traces) and recorded from the layer of Purkinje cell bodies in the cerebellum. A negative wave with spike discharges is followed by a positive wave $(P)$ which is associated with an inhibitory hyperpolarization of the cell-body membrane (ref. 18). CON, contro response before strychnine. $D$ and $E$ are similar responses after intravenous injection of 0.1 and $0.2 \mathrm{mg}$ strychniue hydrochloride per $\mathrm{kg}$ respectively. $F$, responses recorded from the ventrobasal complex of the thalamus $(T H)$ and the post-cruciate gyrus $(C O R T)$ in response to a combined volley in the contralateral superficial radial $(S R)$ and ulnar $(U)$ nerves after intravenous injection of $0.9 \mathrm{mg} / \mathrm{kg}$ strychnine hydrochloride. Both the thalamic positive wave $(P)$ in $F$ and the repetitive $P$-waves in $G$ are associated with large inhibitory postsynaptic potentials (refs. 20,21 ) and are resistant to this large dose of 